Preprints of the

Max Planck Institute for

Research on Collective Goods

Bonn 2011/22

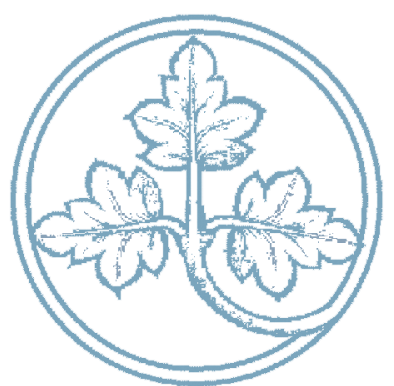

Avoiding the Common

Wisdom Fallacy: The Role

of Social Sciences in

Constitutional Adjudication

Niels Petersen

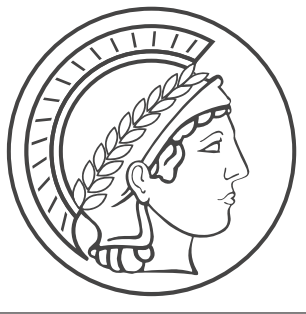




\title{
Avoiding the Common Wisdom Fallacy: The Role of Social Sciences in Constitutional Adjudication
}

\author{
Niels Petersen
}

September 2011 


\title{
Avoiding the Common Wisdom Fallacy: The Role of Social Sciences in Constitutional Adjudication
}

\author{
Niels Petersen*
}

\begin{abstract}
More than one hundred years ago, the U.S. Supreme Court started to refer to social science evidence in its judgments. However, this has not resonated with many constitutional courts outside the United States, in particular in continental Europe. This contribution has a twofold aim. First, it tries to show that legal reasoning in constitutional law is often based on empirical assumptions so that there is a strong need for the use of social sciences. However, constitutional courts often lack the necessary expertise to deal with empirical questions. Therefore, I will discuss three potential strategies to make use of social science evidence. Judges can interpret social facts on their own, they can afford a margin of appreciation to the legislator, or they can defer the question to social science experts. It will be argued that none of these strategies is satisfactory so that courts will have to employ a combination of different strategies. In order to illustrate the argument, I will discuss decisions of different jurisdictions, including the United States, Canada, Germany and South Africa.
\end{abstract}

Keywords: constitutional law, comparative law, Canada, Germany, South Africa, social sciences, empiricism, proportionality, uncertainty, margin of appreciation

Dr. iur. (Frankfurt), M.A. (Columbia), Senior Research Fellow at the Max Planck Institute for Research on Collective Goods, Bonn. I am grateful to Christoph Engel, Yoan Hermstrüwer, Stefan Kadelbach and Emanuel Towfigh for valuable comments and advice. 


\section{Introduction}

The discussion on the role of social sciences in constitutional adjudication has a long history. More than one hundred years ago, the U.S. Supreme Court acknowledged that social science evidence can play a significant role in the interpretation of the constitution. ${ }^{1}$ In Muller v. Oregon, the Court had to decide whether labor regulation for the protection of women violated the due process clause of the Fourteenth Amendment of the U.S. Constitution. ${ }^{2}$ It based its argument on social science evidence showing that women were in need of labor protection and concluded that the legislature had a rational basis for enacting the statute. Nearly half a century later, the Supreme Court used social science evidence at the heart of another groundbreaking decision. In Brown v. Board of Education, the Court used psychological evidence to establish that the racial segregation of schools caused psychological harm to black students and thus violated the Equal Protection Clause of the Fourteenth Amendment. ${ }^{3}$

However, this long history of the use of social science evidence in U.S. constitutional law has not resonated with many other constitutional courts. In particular in continental constitutional adjudication, social science approaches play a marginal role. Although economic thinking has some influence on the scholarship in private or antitrust law on the European continent, ${ }^{4}$ the same development cannot be observed in the realm of constitutional law. ${ }^{5}$ There are probably two principal reasons for this observation. On the one hand, the most popular social science approach in legal scholarship is the economic analysis of law. This economic analysis is often based on micro-economic theory, which deals with the interaction of individuals. Constitutional law often deals with societal phenomena that are considerably broader and for which the toolkit of micro-economic theory often does not fit.

On the other hand, there is a strict separation between the is and the ought in legal argumentation. Legal scholarship is mainly concerned with the normative, the world of what ought to be. Therefore, there is a widespread fear that reference to social science approaches carries a hidden normative agenda, which prefers consequentialist over deontological reasoning. However, both concerns are not justified. While it is true that constitutional legal reasoning is not purely consequentialist, it is not exclusively deontological either. This contribution will show that the structure of argumentation in constitutional law frequently has consequentialist elements. Normative arguments are often based on empirical assumptions that need clarification. Furthermore, social science approaches to the law are not limited to micro-economic theory. The constitutional law-

1 On the history of the use of social sciences in the U.S. Supreme Court, see Paul L. Rosen, The Supreme Court and Social Science (1972).

Muller v. Oregon, 208 U.S. 412 (1908).

Brown v. Board of Education of Topeka, 347 U.S. 483 (1954).

See Kristoffel Grechenig \& Martin Gelter, The Transatlantic Divergence in Legal Thought: American Law and Economics vs. German Doctrinalism, 31 Hastings Int'l \& Comp. L. Rev. 295 (2008) (acknowledging that economic thinking, though increasingly popular, has not yet reached the mainstream).

5 For exceptions see, notably, Anne van Aaken, "Rational Choice" in Der Rechtswissenschaft. Zum Stellenwert Der Ökonomischen Theorie Im Recht (2003); Christoph Engel, Herrschaftsausübung bei offener Wirklichkeitsdefinition, in Das Proprium der Rechtswissenschaft 205 (Christoph Engel \& Wolfgang Schön eds., 2007). 
yer may refer to political science, sociology, or cognitive and social psychology in order to illuminate the empirical assumptions of his normative models.

This contribution will draw on examples from four different jurisdictions in order to show the necessity, but also to highlight the difficulties of using social sciences in constitutional adjudication. I have chosen two jurisdictions, which are rather reluctant to deal with social sciences Germany and South Africa -, as well as two, the Canadian and the US American, where the social science implications of constitutional decisions are commonly discussed and reflected. The argument of this contribution will be unfolded in two steps. The first part will demonstrate that normative arguments are often based on implicit empirical assumptions. It will illustrate that constitutional courts often avoid to second-guess these empirical assumptions, although they are indispensable elements of their argument. The second part will compare three different strategies of constitutional courts to deal with the empirical implications of their decisions: courts can concede a margin of appreciation to the legislator, they can defer the empirical questions of their decisions to expert witnesses, or they can answer the empirical questions themselves. However, it is argued that each of these strategies has serious shortcomings. Therefore, courts need to combine different strategies.

\section{Empirical Considerations in Constitutional Adjudication}

\section{Normative Judgments and Empirical Evaluations}

In principle, the realm of the is and the realm of the ought are strictly separate. On the one hand, lawyers and philosophers always warn of the danger of a natural fallacy. ${ }^{6}$ Normative judgments cannot be deduced from merely factual observations. From the fact that power plays a significant role in the international relations between states, we cannot conclude that powerful states are always right in what they do just because they have the power to do so. On the other hand, there is also a normativist fallacy. ${ }^{7}$ Only because a norm makes a specific prescription, we cannot automatically conclude that the world actually looks like the norm prescribes it to be.

However, even if we cannot draw conclusions from the is to the ought and from the ought to the $i s$, this does not mean that both spheres are completely distinct. Rather, they are connected in different ways. First, normative categories shape the way in which we see reality. The identification of social phenomena often depends on our interpretation. ${ }^{8}$ Our knowledge about the world is not only formed through experience, but also through the perspective from which we observe

Seminally George Edward Moore, Principia Ethica (1959).

7 On the danger of the normativist fallacy in legal scholarship, see Anne van Aaken, Funktionale Rechtswissenschaftstheorie für die gesamte Rechtswissenschaft, in Rechtswissenschaftstheorie 79, 88 (Matthias Jestaedt \& Oliver Lepsius eds., 2008).

8 See Clifford Geertz, Thick Description: Toward an Interpretive Theory of Culture, in The Interpretation of Cultures 3, 6 (Clifford Geertz ed., 1973) (giving an example of winks and twitches, which are, as movements, identical so that we need the context to identify their meaning). 
reality. ${ }^{9}$ And this perspective is often influenced by our normative beliefs. If a European who has never been exposed to baseball before in his life watches a ball game between the Yankees and the Red Sox, he will see people throwing a ball, other people trying to hit this ball and running in circles. However, the knowledge of the rules of the game will give a different meaning to what he sees. Furthermore, an intimate knowledge of pitching techniques and batting strategies will influence what he looks for while watching the game. Therefore, two people may watch the same Yankees vs. Red Sox game, but may observe completely different things.

Second, our normative beliefs are also shaped by our knowledge of the world. Making a normative choice between different options presupposes that we are aware of the available options. Furthermore, normative models are often based on empirical assumptions. Therefore, the practical conclusions of a normative argument may be misleading if the normative argument is based on unrealistic empirical assumptions. Let me illustrate this claim with an example. There seems to be agreement today that democracy is the best form of government that we know. ${ }^{10}$ However, there is a vivid discussion in the political science literature on whether democracy has certain socio-economic preconditions, such as the level of economic development, ${ }^{11}$ ethnic and religious homogeneity, ${ }^{12}$ or the cultural background ${ }^{13}$. If we advise the political reform process of a specific country, the answer to the question of socio-economic preconditions will determine whether we recommend an immediate introduction of competitive elections or some intermediate steps.

If we assume that there are certain necessary preconditions for democracy, this form of government loses (at least temporarily) its attraction if these preconditions are not met. Otherwise, we would draw conclusions from the normatively desirable to the state of the world - the identified normativist fallacy. Even if we assume that it is, in principle, possible to implement some form of democracy in every society, regardless of the socio-economic situation, the concrete institutional design that should be recommended will differ significantly depending on the factual sit-

9 Hans-Georg Gadamer, Wahrheit Und Methode. Grundzüge Einer Philosophischen Hermeneutik 270-312 (1960); Charles Taylor, Interpretation and the Sciences of Man, 25 The Review of Metaphysics 3, 10-17 (1971).

10 Armin von Bogdandy, Globalization and Europe: How to Square Democracy, Globalization, and International Law, 15 Eur. J. Int'1 L. 885, 890 (2004).

11 Seminally Seymour Martin Lipset, Some Social Requisites of Democracy: Economic Development and Political Legitimacy, 53 Am. Pol. Sc. Rev. 69 (1959). The question is discussed extremely controversially in the empirical literature, see Kenneth A. Bollen, Political Democracy and the Timing of Development, 44 Am. Soc. Rev. 572 (1979); Kenneth A. Bollen \& Robert W. Jackman, Economic and Noneconomic Determinants of Political Democracy in the 1960s, 1 Res. Pol. Soc. 27 (1985); Larry Diamond, Economic Development and Democracy Reconsidered, in Reexamining Democracy. Essays in Honor of Seymour Martin Lipset 93 (Gary Marks \& Larry Diamond eds., 1992); Robert J. Barro, Democracy and Growth, 1 J. Econ. Growth 1 (1996); John Benedict Londregan \& Keith T. Poole, Does High Income Promote Democracy?, 49 World Politics 1 (1996); Robert J. Barro, Determinants of Democracy, 107 J. Pol. Econ. 158 (1999); Adam Przeworski, Michael E. Alvarez, José Antonio Cheibub \& Fernando Limongi, Democracy and Development: Political Institutions and Well-Being in the World, 1950-1990 (2000); Carles Boix \& Susan C. Stokes, Endogenous Democratization, 55 World Politics 517 (2003); Daron Acemoglu \& James A. Robinson, Economic Origins of Dictatorship and Democracy (2006); David L. Epstein et al., Democratic Transitions, 50 Am. J. Pol. Sc. 551 (2006).

12 See John Stuart Mill, Considerations on Representative Government (1861).

13 This is, e.g., the hypothesis of Samuel P. Huntington, The Clash of Civilizations?, 72 Foreign Aff. 22 (1993). 
uation. It will look different in a homogeneous nation state than in a segmented society ${ }^{14}$ or in a supranational setting ${ }^{15}$.

\section{Empirical Considerations in the Law}

These considerations cannot be transferred without modifications to the sphere of legal argumentation. Lawyers cannot disregard legal norms even if there is social science evidence that puts the appropriateness of the norm into question. ${ }^{16}$ The German constitution stipulates in Art. 20 that Germany is a democratic state and that all sovereign power emanates from the people. ${ }^{17}$ Even if we assumed that the necessary socio-economic preconditions for a stable democracy were lacking in Germany, the constitutional form of government would still only be a democratic one. The social science argument does not trump the legal norm.

But this does not mean that social science evidence is irrelevant for legal argumentation in constitutional law. We could only discard social science evidence as irrelevant if we could exclude consequentialist reasoning from legal argumentation. As soon as we consider consequences as an integral part of our legal argument, we need a social-science-based methodological toolbox to assess these consequences. There are three possible areas in which the consequential considerations may become part of constitutional law reasoning.

The first constellation is the application of equal protection clauses. If an equal protection clause not only covers direct, but also indirect discriminations, we necessarily have to consider the consequences of a potentially discriminating measure. Second, in individual rights adjudication, courts often have to resolve conflicts between competing values. If a measure restricts an individual right in order to promote a public good, courts often have to strike a balance between the two conflicting values. However, they cannot perform such an evaluation without considering the positive and negative consequences the measure has on individual right and public good. Finally, the language of constitutional provisions is often indeterminate. One popular way of determining the scope of constitutional norms is teleological or functionalist reasoning. However, teleological and functionalist arguments both look at the effects or consequences that a specific interpretation has so that we - again - have to recur to methods of empirical assessment. This section will illustrate this point by analyzing cases of constitutional jurisprudence for each of these three categories. However, before we look at these illustrations, we have to deal with a fundamental objection to consequentialist reasoning in constitutional law.

14 See, e.g., Arend Lijphart, Democracy in Plural Societies (1977).

15 See Joseph H.H. Weiler, Ulrich Haltern \& Franz C. Mayer, European Democracy and Its Critique, 18 W. Eur. Pol. 4 (1995); Fritz W. Scharpf, Governing in Europe: Effective and Democratic? (1999); Niels Petersen, The Democracy Concept of the European Union - Coherent Constitutional Principle or Prosaic Declaration of Intent?, in The Unity of the European Constitution 97 (Philipp Dann \& Michal Rynkowski eds., 2006).

16 Christoph Möllers, Gewaltengliederung - Legitimation Und Dogmatik Im Nationalen Und Internationalen Rechtsvergleich 37 (2005).

17 Grundgesetz für die Bundesrepublik Deutschland, May 23, 1949, at art. 20 para. 1. 


\section{a. Consequentialist arguments and the deontological character of rights}

The consequentialist conception of constitutional law interpretation outlined above has been heavily criticized by two of the most important legal and political philosophers of the last century - Ronald Dworkin and Jürgen Habermas. Their critique focuses in particular on the reasoning in the individual rights context. Habermas, who has the narrower conception of the two, claims that individual rights have a deontological character, so that they cannot be included in the costbenefit-analysis of balancing or proportionality tests. ${ }^{18}$ Rights are only respected in their normative value if they are seen on a different level than competing public interests, while the use of balancing tests puts both sides on the same level. ${ }^{19}$ Therefore, he follows Dworkin in perceiving rights as trumps and to resolve conflicts not by means of a proportionality test, but through interpretation of the respective right. ${ }^{20}$

Such a conception would make a considerable difference for our argument. If we perceive constitutional principles as values per se, not just as means to attain underlying ends, teleological interpretation of these principles becomes impossible because we lack a specific telos. Considerations on the functioning of democracy under certain circumstances become irrelevant in such a conception because the maintenance of democracy would be a value as such, not a means for promoting some form of good governance. However, such a conception begs the question of why specific norms should be protected in such a strong manner. Even constitutional norms need justification if they should not just be a matter of belief or ideology. Then, it seems implausible only to consider this justification for the draft of the norm, but not for its interpretation.

With regard to proportionality, a purely deontological conception of rights would make the justification of infringements of individual rights for the purpose of the public good impossible. Conflicts between individual rights and the promotion of certain public goals would have to be resolved through the interpretation of the scope of the right. The ultimate goal of such a conception would be the attainment of consistency. ${ }^{21}$ Conflicts between competing norms would then have to be resolved in the abstract in order to form a consistent system of constitutional norms. ${ }^{22}$ However, in a complex, modern society, such an abstract hierarchization of values will be close to impossible. ${ }^{23}$

For this reason, Dworkin attenuates his conception of absolute rights and acknowledges the need for some restriction. The most important ground for restricting an individual right is the protec-

18 Jürgen Habermas, Between Facts and Norms: Contributions to a Discourse Theory of Law and Democracy 260 (1996) [Original: Faktizität und Geltung 316 (1992)]. See also Ronald Dworkin, Taking Rights Seriously 193 (1977) (arguing that "[t]he prospect of utilitarian gains cannot justify preventing a man from doing what he has a right to do").

19 Habermas, supra note 18 , at 259.

$20 \quad I d$., at 260.

21 Cf. Ronald Dworkin, Law' Empire 225 (1986).

22 Habermas, supra note 18, at 261.

23 Mattias Kumm, Liberale Gerechtigkeitstheorien und die Struktur der Grundrechte, in Juristische Grundlagenforschung 218, 220 (Robert Alexy ed., 2005). See also Christoph Engel, Inconsistency in the Law: In Search of a Balanced Norm, in Is there Value in Inconsistency? 221, 230 (Christoph Engel \& Lorraine Daston eds., 2006). 
tion of a competing right. ${ }^{24}$ Furthermore, he acknowledges that there may be limitations for 'compelling reasons': ${ }^{25}$

"It cannot be an argument for curtailing a right, once granted, simply that society would pay a further price for extending it. There must be something more special about that further cost, or there must be some other feature of the case, that makes it sensible to say that although great social cost is warranted to protect the original right, this particular cost is not necessary." 26

However, Dworkin cannot explain why rights should impose an additional cost on society independent of their content. ${ }^{27} \mathrm{He}$ mentions two reasons for his strong conception of individual rights: first, he refers to the Kantian idea of human dignity and argues that there "are ways of treating a man that are inconsistent with recognizing him as a full member of the human community". ${ }^{28}$ However, the consequence of this reasoning would be that rights are not considered to be strong per se, but only to the extent to which they promote human dignity. Secondly, he maintains that rights convey political equality because they protect the weaker members of society. ${ }^{29}$ But this may not necessarily be the case, as there are some rights that equally protect the more privileged members of society. Again, this argument does not per se justify a strong conception of rights.

Consequently, there is no compelling moral reason to make the protection of rights costly independent of their content. The reason can only be a formal one. The protection of rights is costly because the society agreed on making it costly. It is thus their adoption in the legal form that attributes them their strong status. ${ }^{30}$ However, this also means that a society is free to attribute a weaker status to individual rights. This is exactly what South Africa and Canada did when they included general limitation clauses into their constitutional rights catalogues. Other countries chose a more mixed approach, such as Germany, where some individual rights have an explicit limitation clause, while others can only be restricted in order to protect a competing right. ${ }^{31}$ Therefore, a purely deontological conception of rights is neither supported by compelling moral reasons nor by the actual legal practice.

\section{b. Equal protection clauses and the assessment of effects}

The application and interpretation of equal protection clauses seems, prima facie, to be an exclusively normative exercise. Whether one group is treated differently than another can usually be identified by just reading the text of the norm. However, not every discrimination is automatical-

Dworkin, supra note 18, at 193.

Id., at 200 .

Id.

François Du Bois, Rights trumped? Balancing in constitutional adjudication, 2004 Acta Juridica 155, 174 (2004).

28 Dworkin, supra note 18, at 198.

29 Id., at 198-99.

30 Du Bois, supra note 27, at 176.

31 Even in the United States, where there are no explicit limitation clauses for constitutional rights, the Supreme Court frequently allows for the restriction of individual rights, see Richard H. Pildes, Why Rights Are Not Trumps: Social Meanings, Expressive Harms, and Constitutionalism, 27 J. Legal Stud. 725, 729 (1998). 
ly illegitimate: legal norms necessarily discriminate by including certain people who fulfill specified characteristics into its scope while excluding others. ${ }^{32}$ Discriminations are only problematic if the aim that is pursued by the discrimination is illegitimate. Some constitutions include an explicit list of reasons for discrimination, which can only be justified under exceptional circumstances. Art. 3 para. 3 of the German constitution, for instance, disallows discriminations on grounds of sex, race, language, origin, religion, or disabilities. In other jurisdictions, the Constitutional Courts have developed similar criteria. The U.S. Supreme Court, for example, applies a strict scrutiny test when the criterion of differentiation is race, alienage, national origin, or gender. $^{33}$

Now, norms can discriminate according to illegitimate criteria in two ways. On the one hand, they can discriminate directly by making the problematic characteristic a criterion of distinction. On the other hand, they can discriminate indirectly. An indirect discrimination is a discrimination that is based on a 'neutral' criterion of distinction, but has a discriminatory effect by privileging or disadvantaging a certain ethnic group or a specific gender. The question of whether there is a discriminatory effect presupposes a normative distinction, but also includes an empirical assessment of the effect of the distinction on the two compared groups.

The most famous example in this respect is the already mentioned U.S. Supreme Court decision of Brown v. Board of Education. ${ }^{34}$ In Brown, the Court had to decide about the constitutionality of segregated schools: did the fact that black and white pupils in some southern states had to visit different schools violate the equal protection clause of the fourteenth amendment? The most important precedent was the decision in Plessy v. Ferguson, in which the Supreme Court had decided that segregation did not violate the equal protection clause. ${ }^{35}$ The Court had argued that whites and blacks were formally treated equally if the provided facilities were of equal quality the famous 'separate but equal doctrine'.

In Brown, the Court found that there was formal equality, as black and white children were provided with equal facilities with regard to all factors. ${ }^{36}$ Therefore, it turned "to the effect of segregation itself on public education". ${ }^{37}$ It found that segregation had a detrimental effect upon colored children because separation policies usually come with a stigma of inferiority that is attributed to one group, which also affected the motivation of children to learn. ${ }^{38}$ In order to support its empirical argument, the Court referred to psychological literature on this issue. ${ }^{39}$ The

32 Winfried Brugger, Grundrechte und Verfassungsgerichtsbarkeit in den Vereinigten Staaten von Amerika 163 (1987).

33 See, e.g., City of Cleburne, Texas v. Cleburne Living Center, Inc., 473 U.S. 432, 439-41 (1985)

34 Brown v. Board of Education of Topeka, 347 U.S. 483 (1954).

35 Plessy v. Ferguson, 163 U.S. 537 (1896).

36 Brown, 347 U.S. at 492.

$37 \quad I d$.

$38 \quad I d$., at 494.

$39 I d$. 
case thus shows that courts often have to recur to the assessment of effects in order to decide discrimination cases. ${ }^{40}$

\section{c. Proportionality and the balancing of competing values}

Many constitutional norms - namely the individual rights guarantees contained in constitutions are not absolute. Many constitutions contain provisions that allow for a restriction of individual rights to promote public interest. Examples are Section 1 of the Canadian Charter of Rights and Freedoms, which stipulates that the rights set out in the Charter are "subject only to such reasonable limits prescribed by law as can be demonstrably justified in a free and democratic society", ${ }^{41}$ or art. 36 of the South African Constitution, according to which

"rights in the Bill of Rights may be limited only in terms of law of general application to the extent that the limitation is reasonable and justifiable in an open and democratic society based on human dignity, equality and freedom". ${ }^{4}$

In such cases, courts are often asked to resolve conflicts between competing rights und collective goods. The most widely used test to solve such conflicts among constitutional courts is the proportionality principle. ${ }^{43}$ According to this principle, a restriction of an individual right is justified if it pursues a legitimate purpose, if there is a rational connection between the measure and the purpose, if there is no less restrictive, but equally effective alternative, and if the protection of the individual rights does not outweigh the promotion of the purpose of restriction.

The empirical implications of the proportionality test seem obvious. ${ }^{44}$ Empirical considerations enter into each of the last three stages of the test. First, whether a specific measure promotes the purpose it is supposed to promote is, in principle, an empirical question. Second, the minimal impairment test compares the effects of different measures with each other. There is, of course, normative judgment involved when it comes to the question of whether a measure is more or less restrictive with regard to an individual right. However, this normative judgment presupposes an idea about the empirical effects of the compared measures.

40 But see the critique of Ronald Dworkin, Social Sciences and Constitutional Rights - the Consequences of Uncertainty, 6 J.L. \& Educ. 3, 4-5 (1977) (arguing that the Court did not need to base its argument on a causal claim, but could have used interpretative social sciences instead).

41 Canadian Charter of Rights and Freedoms, Part I of the Constitution Act, 1982, being schedule B to the Canada Act 1982, ch. 11 (U.K.).

42 Constitution of the Republic of South Africa 1996.

43 See Entscheidungen des Bundesverfassungsgerichts [BVerfGE] 7, 377 (F.R.G.); R v. Oakes, [1986] 1 S.C.R. 103 (Can.); Bank Hamizrahi Hameuchad v. Migdal, C.A. 6821/93, PD 49(4) 221 (1994) (Isr.); S v. Makwanyane and Mchunu (CCT3/94), 1995 (3) SA 391 (S. Afr.).

44 Brun-Otto Bryde, Tatsachenfeststellungen und soziale Wirklichkeit in der Rechtsprechung des Bundesverfassungsgerichts, in Festschrift 50 Jahre Bundesverfassungsgericht, Band I 533, 555 (Peter Badura \& Horst Dreier eds., 2001); Christoph Engel, Das legitime Ziel als Element des Übermaßverbots, in Gemeinwohl in Deutschland, Europa und der Welt 103, 113 (Winfried Brugger, Stephan Kirste \& Michael Anderheiden eds., 2002); Mark Elliott, Proportionality and Deference: The Importance of a Structured Approach, in Effective Judicial Review: A Cornerstone of Good Governance 264, 270 (Christopher Forsyth, Mark Elliott, Swati Jhaveri, Michael Ramsden \& Anne Scully-Hill eds., 2010). See also Indra Spiecker gen. Döhmann, Staatliche Entscheidungen Unter Unsicherheit at ch. 4, part III (forthcoming 2011) (manuscript on file with the author). 
Finally, the balancing at the last stage of the test also has crucial factual implications. Certainly, balancing primarily involves a normative evaluation of preferences of competing values. However, judges applying the proportionality test do not have to rank conflicting interests in the abstract. Rather, the balancing depends on the circumstances of each individual case. These are, in particular, the extent to which the measure in question restricts the individual right at one side of the balance and the degree to which it promotes the public interest at the other side. Both of these aspects are, at least in part, matters of fact that are informed by empirical evidence.

Two cases - one of the Canadian Supreme Court and one of the Constitutional Court of South Africa - may illustrate the empirical implications of the proportionality principle. In one of the first cases after its establishment, $S$ v. Makwanyane, the Constitutional Court of South Africa had to decide on the constitutionality of the death penalty. ${ }^{45}$ The Court found that the death penalty interfered with the prohibition of cruel, inhumane, or degrading treatment and the right to life. The key question of the judgment was whether this interference could be justified under the general limitation clause of the South African Constitution.

In his judgment, President Chaskalson identified two principal goals of the death penalty - deterrence and retribution. ${ }^{46} \mathrm{He}$ then balanced these two goals against the rights of the potential death row candidates. The result of this balancing depends, in part, also on empirical considerations. It will make a difference in our normative judgment whether the death penalty is significantly more effective in deterring crime than long prison sentences. Chaskalson found that there is no evidence that the death penalty is a greater deterrent than imprisonment. ${ }^{47}$ Moreover, retribution alone could not outweigh the right to life and to humane treatment of the death row candidate. For this reason, the Court held that the death sentence was unconstitutional.

A second example for the importance of empirical considerations in the application of the proportionality principle is the judgment of the Canadian Supreme Court in Harper v. Canada. ${ }^{48}$ In Harper, the Court had to decide about a law limiting third-party election advertising expenses. As it restricted the opportunity for private persons to declare their political opinion publicly in the context of elections, the law was found to be in conflict with the freedom of expression guaranteed by section 2 (b) of the Canadian Charter. The question was whether this limitation could be justified under section 1 of the Charter. For this test, the Canadian Supreme Court applied the proportionality principle.

The purpose of the spending limitation was to guarantee electoral fairness. The legislator wanted to prevent rich people from having more influence on the political debate and thus, presumably, also on the election outcome. The crucial question discussed among the judges of the case was an empirical one: to what extent does election advertising - and thus wealth - have an influence on the election results? The minority contended that there was no conclusive evidence that limit-

45 See Makwanyane, supra note 43.

46 See id., at $1116-31$.

$47 \quad I d$., at 9127.

48 Harper v. Canada (Attorney General), [2004] 1 S.C.R. 827. 
less spending on election advertising could distort the election process. ${ }^{49}$ As it was thus unclear whether the law in question could adequately serve its purpose, namely protecting the fairness of the electoral process, the minority argued that protection of the freedom of political expression outweighed the goal of the spending limitations. ${ }^{50}$

In contrast, the majority emphasized that wealth was the main obstacle to equal participation in the political debate. ${ }^{51}$ They acknowledged that it was almost impossible to measure electoral unfairness and its consequences scientifically. ${ }^{52}$ However, they found that it was the task of the parliament to deal with this empirical uncertainty because "the electoral system [...] reflects a political choice, the details of which are better left to parliament." ${ }^{, 53}$ The debate in Harper, therefore, illustrates two important aspects. On the one hand, it underlines the importance of empirical considerations for constitutional judgments and for decisions guided by the principle of proportionality. On the other hand, it shows that the question of how to deal with empirical uncertainty is crucial. Majority and minority both agreed on that there was scarce evidence on the effect of spending on electoral advertising on election results. However, they disagreed about how to evaluate this empirical uncertainty. We will get back to this question in the second part of this paper.

\section{d. The indeterminacy of open-textured constitutional provisions}

The philosophy of Immanuel Kant teaches us that legal decisions cannot exclusively be derived from abstract legal concepts by the mere exercise of logical deduction. ${ }^{54}$ This is particularly valid for the often open-textured provisions of constitutions. In our world, we often observe phenomena of different shades and grades, of more or less. Legal concepts are, in contrast, often categorical. They require us to make a binary decision of yes or no, legal or illegal. The text of the norm often does not help us to determine a cut-off point.

In our democracy example, there is not only one single institutional design of government that can be qualified as a democracy. Instead, there may be democracies of different shades and grades. Some forms of government are clearly democratic, while we can exclude others without much difficulty from the concept of democracy. However, there may be many forms in between, where the question of whether such a form of government can be qualified as democratic or not will be controversially discussed. ${ }^{55}$ In such situations, constitutional courts often recur to teleological or functionalist ways of interpretation in order to specify the abstract legal concepts of the constitution. But this teleological reasoning does not differ to a great extent from the general

$49 I d$., at 934 (McLachlin C.J. and Major J. in part dissenting).

$50 \quad I d$. , at 935 .

$51 \quad I d$. , at 92 (Bastarache J.).

$52 \quad I d$. at 979.

$53 \quad I d$., at 987.

54 Immanuel Kant, Critique of Pure Reason 106-113 (John Miller Dow Meiklejohn trans., Colonial Press 1900) (1781) [German: Kritik der reinen Vernunft A 130-147 (Wissenschaftliche Buchgesellschaft Darmstadt 1983) (1781)].

55 On the gradual nature of democracy see Giovanni Sartori, The Theory of Democracy Revisited 184-185 (1987). 
normative reasoning of the previous section, so that empirical assumptions often play a crucial role in this respect. ${ }^{56}$

One recent case from the German constitutional court may illustrate this point. In the Lisbon judgment, the Court had to decide about the constitutionality of the Lisbon treaty changing the institutional structure of the European Union and transferring certain competencies from the member states to the EU institutions. ${ }^{57}$ The question was whether the treaty violated the principle of democracy of the German constitution, according to which all sovereign power emanates from the people. The applicants argued that the European institutions do not possess sufficient democratic legitimacy and that the exercise of sovereign power by the EU thus violated their right to vote.

Although the Constitutional Court held that the Lisbon treaty did not violate the German constitution, it imposed certain limits on the future transfer of sovereign power to the European Union. It identified certain areas of competence, which have to remain with the nation state in order to respect the democracy principle. ${ }^{58}$ What is interesting with respect to our analysis is the reasoning of the Court. The argument is purely deductive as if the court derived its decision exclusively from the relevant constitutional norms. The Court argued that public debate was one of the crucial and constitutive elements of democracy. ${ }^{59}$ However, according to the judgment, public debate of political issues is to a great extent linked to "patterns of identification related to the nation-state, language, history, and culture". ${ }^{60}$ Therefore, the Bundesverfassungsgericht draws the conclusion that the exercise of the identified core competencies of the nation state by a supranational organization like the European Union would lead to a structural democracy deficit. ${ }^{61}$

The two premises on which the judgment bases its main conclusion are both empirical assumptions. For the first assumption that democracy is dependent on public debate, the Court offers at least a plausible common-sense argument. Public debate is necessary to evaluate the political output of government and parliament and to hold the relevant political actors accountable. ${ }^{62}$ More problematic is the second assumption. The Court supposes that public debate is necessarily linked to the nation state. ${ }^{63}$ Furthermore, it implicitly assumes that political actors on the European level can only be held accountable if there is a uniform public debate in the whole of Europe. However, it does not substantiate this point. In the judgment, we only find the assertion that the compellingly national character of public debate "cannot be overlooked". ${ }^{4}$ The Court

56 Christoph Engel, The Difficult Reception of Rigorous Descriptive Social Science in the Law, in Who Owns Knowledge? - Knowledge and the Law 169, 192 (Nico Stehr \& Bernd Weiler eds., 2008).

57 Bundesverfassungsgericht [BVerfG] [Constitutional Court] June 30, 2009, 123 Entscheidungen des Bundesverfassungsgerichts 267 (F.R.G.). English translation at http://www.bundesverfassungsgericht.de.

58 On this 'innovation' of the judgment, see Daniel Halberstam \& Christoph Möllers, The German Constitutional Court says “Ja zu Deutschland!”, 10 German L.J. 1241, 1250 (2009).

59 BVerfG, supra note 57, at $\uparrow 250$.

$60 \quad I d$. at 9251 .

$61 \quad I d$., at 254.

$62 \quad I d$., at 1268.

63 This argument goes back to Dieter Grimm, Does Europe Need a Constitution?, 1 Eur. L.J. 282, 292-297 (1995).

64 BVerfG, supra note 57, at 9251. 
seems to assume that the empirical assumption is intuitively plausible because we search in vain for at least traces of an argument. ${ }^{65}$ However, intuition cannot replace an argument - in particular if the underlying empirical question is as controversially debated as the one the Court refers to.

\section{Possible Strategies to deal with Empirical Questions}

Judges are no social scientists. They are usually trained in normative reasoning and (con-) textual interpretation, but not necessarily in the technique of making causal inferences or interpreting social phenomena. Nevertheless, there are three potential ways in which constitutional courts can deal with the empirical questions underlying their normative reasoning. First, they can reserve the evaluation of empirical questions to their own judgment, relying either on their intuition or on available social science evidence. This strategy has, in particular, been followed by the German Constitutional Court. ${ }^{66}$ However, this approach has certain disadvantages. As judges are, most often, not trained in empirical research, they may not be aware of its potential pitfalls. I will demonstrate this analyzing a recent decision of the Bundesverfassungsgericht on the smoking ban in bars and restaurants.

The remaining two approaches are deferential ones. On the one hand, courts can grant a margin of appreciation for evaluating social facts to the legislator. This seems to be the preferred strategy of the Canadian Supreme Court. However, this approach is also problematic because it is difficult to determine the limits of the legislative margin of appreciation. We will look at a few decisions of the Canadian court in order to illustrate this point. On the other hand, courts can also defer the assessment of empirical questions to expert witnesses. However, even in these cases, judges have to be aware not to draw wrong inferences from the expert opinions.

\section{Judicial Expertise and the Common Wisdom Fallacy}

In continental legal systems, the evaluation and interpretation of social facts is often perceived to be part of the judicial domain. The Lisbon case of the German Constitutional Court already indicated that continental judges often base their normative judgments on their intuition about social and societal interrelations. If the basis for this intuition is not revealed, disagreement about the interpretation of social facts may quickly turn into a war of competing beliefs and ideologies. However, even if judgments refer to scientific evidence, on which they base their decisions, the judges should be aware of what they are doing. As most judges lack training in social sciences,

$65 C f$. Bryde, supra note 44, 560 (critically referring to this kind of strategy as construction of an image of reality guided by normative considerations). This is not only a problem of the German Constitutional Court. For a similar strategy of the U.S. Supreme Court concerning psychological evidence on the effectiveness of jury decision-making, see J. Alexander Tanford, The Limits of a Scientific Jurisprudence: The Supreme Court and Psychology, 66 Ind. L.J. 137, 144 (1990).

66 See Oliver Lepsius, Sozialwissenschaften im Verfassungsrecht - Amerika als Vorbild?, 60 Juristenzeitung 1, 4 (2005). 
they may not be adequately equipped against the potential pitfalls of social science research. A recent case of the German Constitutional Court may illustrate this point.

In the smoking ban case, the Bundesverfassungsgericht had to decide about the constitutionality of smoking ban laws that had been enacted by the German states (Länder) Berlin and BadenWürttemberg. ${ }^{67}$ These laws basically prohibited smoking in restaurants, bars, and nightclubs, with a few exceptions. The owners of some of these establishments took action against these bans because they feared a massive reduction of revenues and thus believed that the prohibitions violated their freedom of profession. According to the German Constitution, every German citizen has the right freely to pursue his or her profession. ${ }^{68}$ The smoking ban laws restrict this constitutional guarantee because they imposed limits on the kind of services the owners of these businesses could offer. ${ }^{69}$ The key question of the judgment was thus whether this restriction could be justified under the limitation clause of the provision.

The core of the analysis of limitation clauses in the individual rights jurisprudence of the German Constitutional Court is usually the last step of the proportionality test - the balancing of the pursued public good against the infringed individual right. ${ }^{70}$ In the smoking ban case, the court thus had to weigh the protection of the health of the passive smokers against the professional freedom of the owners of the bars and the restaurants. This balancing requires an idea about the empirical effects of the enacted law. To what extent does the smoking ban protect the health of the passive smokers? Is smoke a mere nuisance or does it constitute a serious risk to long-term health? On the other side of the coin, the Court also had to consider the effects of the prohibition on the revenues in the gastronomic industry. The less serious the financial effects, the stronger the case for the defense of the statute.

With respect to health protection, the Court referred to medical expert opinions in order to see whether the legislator had based the statute on a sufficient factual basis. ${ }^{71}$ Although the Court acknowledges that there is some scientific uncertainty with regard to the extent of the negative effect of passive smoking on health, the Court attributes a margin of appreciation to the legislator to give the benefit of the doubt to the decision of the elected legislator. ${ }^{72}$

In contrast to the medical expertise on the health effects, the Court considers the evaluation of the social effects regarding the severity of the restriction of the freedom of profession to be in its own expertise. In principle, it based its opinion in this respect on a press release of the Federal Office for Statistics. ${ }^{73}$ Not all German states had introduced smoking ban laws at the same time.

67 BVerfG, July 30, 2008, 121 BVerfGE 317 (F.R.G.).

68 Grundgesetz, supra note 17, at art. 12.

69 BVerfG, supra note 67, at 345.

70 See Dieter Grimm, Proportionality in Canadian and German Jurisprudence, 57 U. Toronto L.J. 383, 393 (2007).

71 BVerfG, supra note 67, at 352.

$72 I d$., at 352-53. For a critique of the evaluation of the medical expertise, see Stefan Brink, Tatsachengrundlagen verfassungsgerichtlicher Judikate, in Linien der Rechtsprechung des Bundesverfassungsgerichts - erörtert von den wissenschaftlichen Mitarbeitern 3, 24-26 (Hartmut Rensen \& Stefan Brink eds., 2009). Cf. Pressemitteilung des Statistischen Bundesamtes 207/08 (June 6, 2008). 
The press release analyzed the development of the revenues in the states with smoking ban laws and those without smoking ban laws. It stated that there was a higher decrease in revenues in states with a smoking ban than in states without a smoking ban. ${ }^{74}$ Because of this press release, the Constitutional Court came to the conclusion that the smoking ban had a negative causal effect on the revenue of the gastronomic industry, ${ }^{75}$ which was one reason for finally striking down the smoking ban laws, declaring them unconstitutional.

However, this conclusion seems to be premature. There are several reasons why the revenue numbers could differ. The revenue development of the gastronomic industry is influenced by different factors, which are not necessarily the same in all states. The Court could thus not draw solid conclusions from the comparison without looking at whether the difference was statistically significant. If it was not, then the difference could very well be due to other factors not related to the introduction of the smoking ban. Such factors could be the weather or the general economic development in the specific state.

Unfortunately, it was impossible for me to get the relevant information from the Federal Office of Statistics to calculate statistical significance. However, it was possible to get data from the various state offices of statistics and these should give us an intuition for why the conclusions of the Bundesverfassungsgericht are problematic. ${ }^{76}$ It seems intuitively plausible that it is more likely that the numbers show at least a correlation between the smoking ban and the revenue development if the variance within the two compared groups of states is relatively small. A small variance means that the states are rather homogenous and the other factors that might play a role have about the same effect in every state. However, a large variance would indicate that there is a great divergence in the extent to which other factors influence the development of the revenue in each particular state. Therefore, if we observe a large variance, it seems unlikely that the smoking ban is the main culprit for the observed difference in revenue development.

In the third quarter of 2007, the revenue development in the observed sample ranged from $-1.9 \%$ in Baden-Württemberg (a state with a smoking ban) to $-21.7 \%$ in Mecklenburg-Vorpommern (a state without a smoking ban). In the fourth quarter of 2007, it ranged from $-2.5 \%$ in SchleswigHolstein (without a smoking ban) to $-14.9 \%$ in Lower Saxony (with a smoking ban). Consequently, the variance between the different states is considerable. In the third quarter of 2007, it was nearly 20 percentage points. Furthermore, the worst development could not always be observed in states with a smoking ban. At the same time, the state with the best development within the sample in the third quarter of 2007 was a state with a smoking ban provisions. These considerations suggest that the Constitutional Court could not draw the conclusions that it drew from the press release.

74 In the two states with a smoking ban, the revenue decreased by $9.8 \%$, while it only decreased by $6.8 \%$ in the 14 states without a smoking ban in the third quarter of 2007. In the fourth quarter of 2007, the three states with a smoking ban had a revenue decrease of $14.1 \%$ and the thirteen states without a smoking ban a decrease of $8.8 \%$.

75 BVerfG, supra note 67, at 355 and 364.

76 The data is taken from Niels Petersen, Braucht die Rechtswissenschaft eine empirische Wende?, 49 Der Staat 435, 449-450 (2010). 
The lessons of this judgment are rather simple. Social sciences have developed useful rules to evaluate what conclusions we can draw from observations that we make. ${ }^{77}$ It might be that these observations are expressions of a more general social regularity, showing that there is a causal relation between specific phenomena that we observe. However, the simultaneous appearance of these phenomena may also be due to chance or other factors that we could not observe. If lawyers are ignorant of these rules and think that they have the expertise to make the evaluation of social facts, it is well possible that they base their normative conclusions on questionable factual assumptions. $^{78}$

\section{Deferential Strategy I: Legislative Margin of Appreciation}

A second strategy to deal with the question of empirical uncertainty is giving the legislator a margin of appreciation in determining and evaluating the factual basis of its decisions. The principal assumption behind deferring the evaluation of the empirical basis of decisions to the legislator is that the legislator as an elected body has a greater extent of legitimacy for determining these questions than courts. Deference, therefore, means to show some form of subordination to the elected political organs and to leave the political decisions to the political branches. ${ }^{79}$ However, in this generality, the argument is in danger of being circular. I do not want to enter into the discussion on the legitimacy of constitutional review at this point. ${ }^{80}$ But if we assume that constitutional courts have a legitimate function in controlling the legislator, we cannot derive limitations of the courts' competence from the greater legitimacy of the legislator, as this begs the question.

If we take a closer look, political decisions usually consist of two, though not entirely separable elements. ${ }^{81}$ On the one hand, we have policy choices, which should be representations of collective preferences. Although there is no perfect mechanism to translate accumulated individual preferences into one collective preference, ${ }^{82}$ parliament is the best institution to deal with this transformation. On the other hand, we have strategies of implementation, which comprise all the

77 Of course, social science research is not limited to making claims about causal inferences. There is also an interpretive strand in the social sciences, see Taylor, supra note 9; Dworkin, supra note 40, at 3-4; David Dessler \& John Owen, Constructivism and the Problem of Explanation, 3 Perspectives on Politics 597 (2005).

78 See also Andreas Voßkuhle, Das Konzept des rationalen Staates, in Governance von und durch Wissen 13, 24 (Gunnar Folke Schuppert \& Andreas Voßkuhle eds., 2008) (cautioning against a blind reliance on quantitative facts).

79 See David M. Beatty, Law and Politics, 44 Am. J. Comp. L. 131, 134 (1996).

80 On this discussion see, e.g., Alexander M. Bickel, The Least Dangerous Branch (1962); John Hart Ely, Democracy and Distrust (1980); Ulrich Haltern, Verfassungsgerichtsbarkeit, Demokratie Und Mißtrauen (1998); Jeremy Waldron, Law and Disagreement (1999); David M. Beatty, The Ultimate Rule of Law (2004); Dimitris Kyritsis, Representation and Waldron's Objection to Judicial Review, 26 Oxford J. Legal Stud. 733 (2006); Richard Bellamy, Political Constitutionalism. A Republican Defense of the Constitutionality of Democracy (2007); Michael J. Perry, Constitutional Rights, Moral Controversy, and the Supreme Court (2009); Grégoire C.N. Webber, The Negotiable Constitution (2009); David Robertson, The Judge as Political Theorist (2010).

81 Anthony Downs, An Economic Theory of Democracy 4 (1965).

82 See Kenneth J. Arrow, A Difficulty in the Concept of Social Welfare, 58 J. Pol. Econ. 328 (1950). 
measures to attain the identified policy choice. In theory, one can distinguish between more or less effective measures of implementation. At least as far as individual rights are concerned, parliament is not free to choose the less efficient over the more efficient measure. ${ }^{83}$ Instead, the cost-benefit analysis structure of the proportionality principle requires the legislator to take the most rational decision.

One crucial part of the rationality of the implementation strategy is the accuracy of factual prognoses. A measure that is based on an arbitrary empirical assumption can itself not be more rational than the assumption. In a world without empirical uncertainty, there would thus be no reason to convey any margin of appreciation to the legislator with regard to the factual basis of its decision. However, we do not live in a world without factual uncertainty. It is often impossible to say whether a factual assumption is right or wrong. Therefore, some scholars argue that courts should not second-guess the empirical basis of legislative decisions because parliament generally has a greater pool of resources and is thus better suited for clarifying empirical uncertainty than courts. $^{84}$

However, this does not mean that it is per se reasonable to assume that the legislator makes a proper factual prognosis. ${ }^{85}$ One of the reasons for failing to make proper use of the prognostic resources may be political incentives. One example should illustrate this idea. Let us assume that there is a public outrage against sexual violence. For this reason, government and parliamentary majority enact a law, imposing the death penalty on sex offenders. The government argues that this will deter potential offenders and decrease the number of criminal acts. For the politicians supporting the initiative, it is not important whether this is actually true. What is important is that the public believes that this is true. Therefore, the government has no incentive to do research on the underlying empirical assumptions.

Therefore, we need clearly defined limits of the legislative margin of appreciation if we do not want judicial review to be turned into a blunt instrument. ${ }^{86}$ There is doubt in the legal literature whether it is possible to delimit clearly the legislative margin of appreciation in empirical questions. ${ }^{87}$ In the following, I will discuss two possible models of deference. On the one hand, courts can grant a margin of appreciation to the legislator in cases in which social science evidence in inconclusive (a.). On the other hand, they can exercise a mere procedural control without evaluating the substance of the empirical prognosis (b.).

83 See Aaken, supra note 5, at 315-333.

84 Jeffrie G. Murphy \& Jules L. Coleman, Philosophy of Law. An Introduction to Jurisprudence 228 (1990). Cf. also Horst Eidenmüller, Effizienz Als Rechtspinzip 428 (1995).

85 Joseph H.H. Weiler, Comment: Brazil - Measures Affecting Imports of Retreaded Tyres (DS32), 8 World Trade Rev. 137, 144 (2009).

86 Julian Rivers, Proportionality, Discretion and the Second Law of Balancing, in Law, Rights and Discourse. The Legal Philosophy of Robert Alexy 167, 183 (George Pavlakos ed., 2007).

87 See Julian Rivers, Proportionality and Variable Intensity of Review, 65 Cambridge L.J. 174, $202-206$ (2006); Elliott, supra note 44, at 272-276. 


\section{a. Inconclusiveness of Social Science Evidence}

The first strategy that can be employed by courts is deferring the decision to the legislator if the social science evidence is inconclusive. We have seen that empirical uncertainty is the main justification for affording a legislative margin of appreciation. In such a situation, making factual assumptions is not a question of more or less rationality, but about societal risk preferences. To illustrate this point, let us return to the smoking ban case from above and assume that there is inconclusive social science evidence on the health effects of passive smoking. Then the conclusions we draw from this evidence depend on whether we prefer to be cautious with regard to potential negative health effects or whether we confide in the negative health effects being negligible. This is not a question that science can answer, ${ }^{88}$ but a normative question of preferences that has to be answered by political bodies accountable to the electorate - not by the courts. ${ }^{89}$

This approach of granting the legislator a margin of appreciation if the social science evidence is inconclusive can be observed in many decisions of the Canadian Supreme Court. ${ }^{90}$ In Irwin Toy, the Court had to decide whether a prohibition for commercial advertising directed at persons under thirteen years of age enacted by the legislature of Quebec violated the freedom of expression enshrined in the Canadian Charter of Rights and Freedoms. ${ }^{91}$ The Court found that the freedom of expression was infringed by the provision and thus had to analyze whether the restriction could be justified under section 1 of the Charter.

The aim of the advertising prohibition was to protect young children against the manipulative effects of commercial advertising. In assessing whether this was a pressing and substantial concern in terms of the Oakes test, which is the Canadian version of the proportionality test, the Court principally relied on a scientific report of the U.S. Federal Trade Commission. ${ }^{92}$ The report found that children under six years of age are unable to distinguish fact from fiction and are thus very exposed to the seductions of commercial advertising. Furthermore, it stated that children generally develop the cognitive ability to recognize the persuasive nature of advertising at some point between the age of seven and adolescence. ${ }^{93}$

Based on this scientific evidence, the Court had to assess whether choosing the age of thirteen as the cut-off age was arbitrary. It argued that

88 See Joseph H.H. Weiler, Epilogue: Towards a Common Law of International Trade, in The EU, the WTO, and the NAFTA. Towards a Common Law of International Trade? 201, 222-223 (Joseph H.H. Weiler ed., 2000).

89 See Ulrich Haltern, Europarecht: Dogmatik Im Kontext 1646 (2nd ed. 2007).

90 A similar approach is also taken by the European Court of Justice, which grants the member states discretion as to the level of protection they want to convey to their citizens "in so far as there are uncertainties at the present state of scientific research" (Case 174/82, Sandoz, 1983 E.C.R. 2445, at 916 ).

91 Irwin Toy Ltd v. Quebec (Attorney General), [1989] 1 S.C.R. 927.

$92 I d$., at 988.

$93 \quad I d$., at 989. 
"[i]f the legislature has made a reasonable assessment as to where the line is most properly drawn, especially if the assessment involves weighing conflicting scientific evidence and allocating scarce resources on this basis, it is not for the court to second guess. That would only be to substitute one estimate for another." 94

Therefore, the Court afforded the legislator a margin of appreciation "to form legitimate objectives based on somewhat inconclusive social science evidence." 95

However, this approach has one fundamental problem: it is up to the courts to decide whether the social science evidence is inconclusive. The Courts thus have to make their own assessment of the social science evidence. Therefore, they have to be aware of the pitfalls highlighted in the previous section with regard to the smoking ban judgment of the German Constitutional Court. Furthermore, they have to determine standards for evaluating whether the social science evidence is conclusive or not. However, this will be difficult to determine because there are probably few relevant questions on which there is no scientific debate. Consequently, there is often severe disagreement among the judges of the Canadian Supreme Court on whether the social science evidence is inconclusive. ${ }^{96}$

In RJR-MacDonald, the Court had to decide about the constitutionality of a total ban of tobacco advertising. ${ }^{97}$ The Court agreed that the tobacco advertising ban violated the freedom of expression guaranteed by the Canadian Charter of Rights and Freedoms, as the latter also includes the freedom of commercial expression. ${ }^{98}$ The crucial question of the case was thus again whether the restriction could be justified. In their analysis of section 1, the judges had to decide whether tobacco advertising indeed increased tobacco consumption. The majority made a distinction between lifestyle advertising and other forms of advertising, such as informational advertising, reminders of package appearance, information about the relative tar content or about new brands. It found that there was no scientific evidence that the latter forms of advertising led to an increase in tobacco consumption. ${ }^{99}$ It imposed the burden of proof concerning this evidence on the legislator. As the latter had not produced any evidence, the majority held that the advertising ban failed the rational connection ${ }^{100}$ and the minimal impairment tests. ${ }^{101}$

In his dissenting opinion, representing the three judges of the minority, Justice La Forest acknowledged that the social science evidence on whether all forms of tobacco advertising were harmful to potential tobacco consumers was inconclusive. However, he drew different conclusions. Reminding the majority of the mentioned passage in Irwin Toy, he argued that the legislator should be given a margin of appreciation in cases of inconclusive social science evidence. ${ }^{102}$

$94 \quad I d$. , at 990.

$95 I d$.

96 Sujit Choudhry, So What Is the Real Legacy of Oakes? Two Decades of Proportionality Analysis under the Canadian Charter's Section 1, 34 Sup. Ct. L. Rev. 501, 527-528 (2006).

97 RJR-MacDonald v. Canada (Attorney General), [1995] 3 S.C.R. 199 (Can.).

$98 \quad I d$., at 124 (McLachlin J.).

$99 \quad I d$., at 159.

100 Id.

$101 \quad I d$., at 9163.

102 Id., at 104 (La Forest J. dissenting). 
According to his opinion, it was not the role of the courts to draw the line between harmful and non-harmful ways of tobacco advertising.

This reasoning was harshly rejected by the majority. Justice McLachlin argued in her majority opinion that

"the challenged law [cannot be treated] as a unique socio-economic phenomenon, of which Parliament is deemed the best judge. This would be to undercut the obligation on Parliament to justify limitations which it places on Charter rights". ${ }^{103}$

She went on to say that

"[t]o carry judicial deference to the point of accepting Parliament's view simply on the basis that the problem is serious and the solution difficult, would be to diminish the role of courts in the constitutional process." 104

The concepts of burden of proof and margin of appreciation have diametrical effects. Imposing a burden of proof on the legislator implicitly assumes that it would have been possible to clarify the empirical question at the center of the debate. The legislator just did a bad job in establishing the factual basis of its decision. ${ }^{105}$ Therefore, the benefit of the doubt is with the applicants invoking a violation of their individual rights. In contrast, affording a margin of appreciation assumes that it was not possible to produce the necessary evidence. The question that the legislator was facing was, therefore, not an empirical question of right or wrong, but a decision about risk preferences in a situation of uncertainty. In this case, the benefit of the doubt is with the legislator.

Consequently, the courts have to analyze the social science discussions to determine whether social science evidence is inconclusive or not. If the government does not provide sufficient evidence, this may have two reasons. It may either be because it did not do a proper job in establishing the empirical basis of its decision. In such a case, it seems justified to impose the burden of proof on the legislator. However, it may also be because it is impossible to produce adequate evidence because of scientific uncertainty. In such a case, it seems legitimate to convey a margin of appreciation to the legislator. But the judges will have difficulties to determine which of the scenarios they deal with without having a closer look at the actual scientific discussion. And even then, they would have to define adequate standards for what actually constitutes inconclusive social science evidence.

\section{b. Procedural Control of Legislative Decisions}

The alternative to assessing whether the social science evidence is inconclusive is a procedural approach. A procedural approach would not analyze whether the material preconditions for a legislative margin of appreciation are fulfilled, but whether the legislator has met the necessary

103 Id., at 9134 (McLachlin J.).

$104 I d$., at 136.

105 In RJR MacDonald, there were some indications in this direction because the government refused to disclose one study that the government had carried out on possible alternatives to a total advertising ban; see id., at 9 166. 
procedural safeguards to take its decision on a sound empirical basis. Courts thus investigate whether the piece of legislation emerges from a reliable process of pre-legislative fact-finding and consultation of expert opinions. ${ }^{106}$ They have to make sure that parliament has made use of its superior resources. However, the evaluation of the facts is totally deferred to the legislator.

Although this procedural approach is advocated by some voices in the constitutional law and human rights scholarship, ${ }^{107}$ it has not yet resonated with the constitutional jurisprudence. Traces of a procedural approach can be found in the dissenting opinion of Judges Binnie and LeBel in the Chaoulli judgment of the Canadian Supreme Court. ${ }^{108}$ In Chaoulli, the applicant had criticized the public healthcare system that led to long waiting times for certain kinds of operations and argued that not having an alternative private health insurance system that could provide better services violated his right to life. The government of Quebec justified the prohibition with the argument that the introduction of a parallel private system would cause an adverse selection and thus lower the quality of the public system.

The main factual question of the case was thus the impact of a parallel private healthcare system on the public service. The majority of the Court held that there was not enough evidence showing that the prohibition of private healthcare was justified. It criticized that the argument of the government was not based on sound evidence, but on the mere "common sense proposition that the improvement of health services depends on exclusivity". ${ }^{109}$ The main factor tipping the balance was the evidence from other Canadian provinces and OECD countries, where parallel systems could coexist if the legislator took measures to protect the public plans from abuse. ${ }^{110}$ Justice Deschamps, who delivered the reasons for the judgment, even went so far to deny any margin of appreciation. He argued that Chaoulli was "a case in which the courts have all the necessary tools to evaluate the government's measure" so that there was no room for deference. $^{111}$

In their dissenting opinion, Judges Binnie and LeBel advocated to afford a margin of appreciation to the legislator. In their reasoning, they show traces of a procedural approach. They relied on the credentials of the experts, on whose opinion the government of Quebec based its opinion, ${ }^{112}$ and argued that Quebec's legislature invested large sums of money in a series of authoritative reports that recommended the retention of a single-tier system. ${ }^{113}$ They thus highlighted that the legislature had made serious efforts to establish the factual basis of its decision and fol-

106 Rivers, supra note 87, at 204.

107 See Choudhry, supra note 96, at 534; Rivers, supra note 87, at 204; Olivier De Schutter \& Françoise Tulkens, Rights in Conflicts: The European Court of Human Rights as a Pragmatic Institution, in Conflicts between Fundamental Rights 169, 208 (Eva Brems ed., 2008). See also Brun-Otto Bryde, Verfassungsentwicklung. Stabilität Und Dynamik Im Verfassungsrecht Der Bundesrepublik Deutschland 328 (1982).

109 Id., at 136 (McLachlin C.J. and Major J.).

$110 I d$., at 92 (Deschamps J.).

$111 I d$., at 96.

$112 I d$., at 9214 . (Binnie and LeBel JJ. dissenting).

$113 I d$., at 9258. 
lowed the recommendations that it got. For this reason, they advocated to respect the legislative decision.

Traces of a procedural approach can also be found in some decisions of the German Constitutional Court. The most prominent of these is a judgment, in which the Court had to decide whether the introduction of corporate participation rights for employees violated fundamental rights of the owners and shareholders of the corporations. ${ }^{114}$ The court acknowledged that the German legislator had a margin of appreciation with regard to the factual prognosis concerning the economic effects of this law. ${ }^{115}$ In order to define the limits of the legislative discretion, the court looked at the procedure and asked whether the legislator had exhausted all possible sources of information and interpreted the information in a plausible way. ${ }^{116}$ However, the court has not developed this approach in a consistent manner in subsequent decisions. ${ }^{117}$

The procedural approach acknowledges that the questions of uncertainty and risk preferences cannot be as neatly separated as the inconclusive evidence approach suggests. There is no objective way to determine whether we have a 'true' situation of uncertainty. Therefore, the procedural approach seems to be conceptually the more coherent perspective. However, its effectiveness depends on determining good standards for evaluating legislative fact finding procedures. And this might be a difficult task. ${ }^{118}$ How do we know whether parliament has done a proper job of legislative fact finding? Do we require expert hearings or scientific studies? How do we determine whether parliament heard the 'right' experts, whether it can be expected that the studies it consulted were methodologically sound? Although the procedural approach has some promising features, it seems to share some of the problems that we also identified in the context of the substantive approach. Therefore, it is not surprising that courts have so far been reluctant to concentrate on a procedural control. There are still too many unanswered questions with regard to the merely procedural standard of review to make it the unrivaled gold standard of testing the empirical basis of legislative decisions.

\section{Deferential Strategy II: Delegation to Experts}

The final way to deal with social science implications of legal questions is to defer the social science questions to experts. Under this approach, courts ask a well-defined question to a social scientist and base the decision on the recommendations of his opinion. Many of the deficiencies of this pure delegation model are known and have already been pointed out in other contributions. ${ }^{119}$ The most important problem is probably that it is difficult to determine the resilience of

114 Bundesverfassungsgericht [BVerfG] [Constitutional Court] March 1, 1979, 50 Entscheidungen des Bundesverfassungsgerichts 290 (F.R.G.).

115 Id., at 332-33.

$116 I d$, at 334.

117 Klaus Meßerschmidt, Gesetzgebungsermessen 845 (2000).

118 See also id., at 871 (arguing that testing for procedural rationality cannot fully replace a substantive control of the legislative decision).

119 See, e.g., John Hagan, Can Social Science Save Us? The Problems and Prospects of Social Science Evidence in Constitutional Litigation, in Charter Litigation 213 (Robert J. Sharpe ed., 1987); Katherine Swinton, What 
the results of a social science study. Without a particular knowledge of the field and its methodologies, a judge will not be able to evaluate the soundness of the research design and the used methods. Furthermore, he does not know whether certain results represent the consensus of the discipline or whether they are deeply contested.

However, I would like to place the emphasis in this section on a different point, which has as yet been less considered in legal scholarship. It concerns the normative implications of empirical studies. ${ }^{120}$ Let us assume that we want to determine the effectiveness of a specific legislative initiative to reduce poverty. For such a study, we would have to conceptualize and operationalize the analyzed variables. ${ }^{121}$ In the context of poverty, this means that we first have to define what we mean by poverty, and then we have to find indicators that can measure the level of poverty as described in our definition. In particular, the first step, the definition, has serious normative implications.

There are three possible ways of defining poverty. First, we may use an absolute standard of poverty. Under this absolute standard, we would define that everybody who has a monthly income of less than a certain fixed amount has to be considered as poor. Second, we can also use a relative standard of poverty, according to which we define everybody as being poor if he or she disposes of less than 50 percent of the monthly median income. While the first standard assumes that everybody needs a certain amount of money to lead a decent life, the second focuses on distributive issues. The number of poor people will rise if the societal income gap increases.

Finally, there is a subjective way of defining poverty. One might ask people about what they were actually able to afford during the last month, whether they could pay their rent, etc. This subjective definition of poverty would also account for the ability to economize. If a person spends a lot of money on alcohol or games, he may not have enough money to afford the basic commodities of daily life, although his income is above the poverty threshold identified under the other two standards.

There is not one 'right' way to define poverty. How we define the concept depends on what we want to know. The first conceptualization aims at whether people have the material opportunity to live a decent life, while the second one is more interested in distributive concerns. The subjective concept finally takes into account that the mere material ability to live a decent life may not be a sufficient condition for actually doing it. Judges have to be aware of these differences because the notion of poverty in the study they consult may be a different one than the understanding that forms the basis of their decision. If judges want to know about the theoretical ability to

do the Courts Want from the Social Sciences?, in Charter Litigation 187 (Robert J. Sharpe ed., 1987); Christoph Engel, Verhaltenswissenschaftliche Analyse: eine Gebrauchsanweisung für Juristen, in Recht und Verhalten 363 (Christoph Engel, Markus Englerth, Jörn Lüdemann \& Indra Spiecker gen. Döhmann eds., 2007); Jörn Lüdemann, Netzwerke, Öffentliches Recht und Rezeptionstheorie, in Netzwerke 266 (Sigrid Boysen et al. eds., 2007); Jörn Lüdemann, Rechtsetzung und Interdisziplinarität in der Verwaltungsrechtswissenschaft, in Öffentliches Recht und Wissenschaftstheorie 125 (Andreas Funke \& Jörn Lüdemann eds., 2009).

120 See also Engel, supra note 56, at 176 (concentrating rather on the normative implications of the interpretation of social science results).

121 Royce A. Singleton \& Bruce C. Straits, Approaches to Social Research 115-25 (5th ed. 2010). 
lead a decent life as it is captured by the absolute standard, a study that finds an increase or a decrease of poverty according to the relative standard does not contain any useful information for the judicial decision. The term used is the same, the concepts are different. Therefore, it is dangerous to consider social sciences as a black box, as a multifunctional brick that can easily be tailored and built into a judicial decision. If they want to use social sciences properly, judges cannot avoid having some basic knowledge of the field and its methodology.

\section{Conclusion}

In constitutional adjudication, judges cannot completely ignore social sciences. Constitutional interpretation and the balancing of competing constitutional values are often based on empirical assumptions. However, even if we agree that constitutional adjudication has to take social sciences into account, the question of what this taking into account may look like is a complex one. Lawyers are usually trained in textual interpretation, in normative comparisons, in making coherent value judgments. In contrast, they are no masters of inferring causality, of determining abstract regularities from a number of factual observations.

In this contribution, I have discussed three different strategies of dealing with the empirical implications of constitutional adjudication - interpreting social facts autonomously, affording a margin of appreciation to the legislator, and deferring the evaluation of social facts to external experts. Some of these strategies are better than others, but none can give a complete answer to the problem of treating empirical questions in legal decisions. The strategy that comes closest, at least in theory, to being a holistic remedy is probably exercising a merely procedural control of legislative decisions, which only examines whether the legislator used a proper procedure to establish the factual basis of his draft. However, this strategy is rarely used by courts in practice, and it is not difficult to see why. The principal problem is that we need to establish effective standards of control, and there remain still too many unresolved issues in this respect.

Until we have developed such standards, the best way to deal with social sciences in constitutional adjudication seems to be a combination of the mentioned strategies. It is unavoidable to afford some margin of appreciation to the legislature in the evaluation of social facts. We live in an uncertain world, and dealing with uncertainty is only to a certain extent about getting the facts right. It is also a question of societal risk preferences, and courts are not the adequate institutions to determine these preferences. However, in order not to transform the margin of appreciation into marginless arbitrariness, courts have to control the limits of parliamentary discretion. The legislator only has a margin of appreciation if the social science evidence is inconclusive.

In order to see whether the legislator had a rational basis for its decision, the courts have to refer to expert witnesses or consider the relevant social science research themselves. However, whatever they do, judges need a basic understanding of social science methodology. If they evaluate data autonomously, they have to know what kind of conclusions they can draw from the facts that they observe. If they look into the social science literature, they have to be able to under- 
stand the limits of the studies they refer to and to evaluate potentially competing claims. Even if they defer the question to expert witnesses, they have to be aware of the normative implications of the empirical studies. Certainly, judges do not have to turn into social scientists. But they cannot be totally ignorant of social science methods either.

This is a task both of legal academia of future legal education. On the one hand, there is a need for legal academics, who act at the interface between law and social sciences. ${ }^{122}$ Such academics may influence the discussion in legal scholarship by identifying questions where social science evidence may be of help and by translating insights of economics, psychology or political science for the legal discipline. On the other hand, it is inevitable that young lawyers get some basic training in social science methods in order to avoid pitfalls in dealing with empirical questions. While North American law schools have already taken necessary steps into the right direction, the universities in continental Europe still have to engage in this transformation. 